$$
\begin{gathered}
\text { 백합식해 발효 중 생화학적 및 미생물학적 특성 변화 } \\
\text { 구재근*·유정희 }{ }^{1} \text {. 박권삼·김선영 }{ }^{1} \\
\text { 군산대학교 식품생명공학과, }{ }^{1}{ }^{2} \text { 산대학교 식품영양각과 }
\end{gathered}
$$

\title{
Biochemical and Microbiological Changes of Hard Clam Shikhae During Fermentation
}

\author{
Jae-Geun Koo*, Jung-Hee Yoo ${ }^{1}$, Kwon-Sam Park and Sun-Young Kim \\ Department of food science and biotechnology, Kunsan National University, \\ Kunsan 573-701, Korea \\ ${ }^{1}$ Department of food and nutrition, Kunsan National University, \\ Kunsan 573-701, Korea
}

The biochemical and microbiological changes of the hard clam shikhae were studied during fermentation at $4-18^{\circ} \mathrm{C}$ for 45 days. For preparation of the shikhae, the shucked hard clams were blanched into $2 \%$ saline solution and were soaked in seasoning solution before mixing with salt, cooked grain and spices. During fermentation, the initial $\mathrm{pH}$ steadily decreased from 5.0 to 4.6 , but $\mathrm{NH}_{2}-\mathrm{N}$ and VBN concentrations increased to $127 \mathrm{mg} / 100 \mathrm{~g}$ and $27.0 \mathrm{mg} / 100 \mathrm{~g}$, respectively. Alanine, taurine, glutamic acid, and aspartic acid concentrations increased, but arginine concentration decreased by fermentation. The major organic acids of the fermented shikhae were lactic acid, succinic acid and acetic acid. The major free sugar were maltose, glucose and fructose. The concentration of total viable cell $\left(2.1 \times 10^{5} \mathrm{CFU} / \mathrm{g}\right)$ and proteolytic bacteria $\left(1.2 \times 10^{5} \mathrm{CFU} / \mathrm{g}\right)$ increased to $4.4 \times 10^{8} \mathrm{CFU} / \mathrm{g}$ and $9.8 \times 10^{7} \mathrm{CFU} / \mathrm{g}$, respectively until day 15 and then slightly decreased. The concentration of yeast $\left(2.4 \times 10^{3} \mathrm{CFU} / \mathrm{g}\right)$ increased to $1.6 \times 10^{7} \mathrm{CFU} / \mathrm{g}$ until day 25 , but lactic acid bacteria $\left(5.0 \times 10^{8} \mathrm{CFU} / \mathrm{g}\right)$ increased to $5.0 \times 10^{8} \mathrm{CFU} / \mathrm{g}$ until day 9. Vibrio species was not detected on the TCBS agar during fermentation.

Key words : Hard Clam, Shikhae, Biochemical Change, Microbiological Change, Fermentation

서 론

식해는 수산물에 소금과 곡류를 넣어 발효, 숙성시킨 식품 으로 소금만 넣어 발효시킨 젓갈에 비해 염도가 낮고 유기산 및 유리당 함량이 높아 저식염 제품을 선호하는 현대인의 기호에 보다 적합하다. 식해는 오랜 역사를 가진 우리의 전통 식품으로 1600 년대 말 주방문 (酒方文)을 비롯한 여러 고문헌 에 어류, 연체류, 갑각류, 패류 등 다양한 종류의 식해가 수록되 어 있다 (Lee and Lee, 1989). 그러나 현재는 가자미식해, 명태 식해, 오징어식해 만이 동해안 일부 지역에서 지역 특산품으 로 소규모로 생산되고 있다. 오랜 전통과 우수한 기호성에도 불구하고 식해가 상업적으로 대중화되지 못한 것은 현재까지 전래된 식해의 종류가 극히 적고 제품의 저장성이 낮아 동해 안 일부 지역을 제외한 지역에서는 식해를 접할 기회가 적었 기 때문이다. 따라서 우리의 우수한 수산 전통식품인 식해 산업의 발전을 위해서는 다양한 종류의 식해 개발과 더불어 저장성을 향상시키기 위한 체계적인 연구가 필요하다. 현재까 지 수행된 식해에 관한 연구는 가자미식해의 발효특성 (Lee et al., 1983; Jung et al., 1992; Souane et al., 1987), 명태식해의 발효특성 (Cha et al., 2004a; Cha et al., 2004b; Choi et al., 2002), 오징어식해의 발효특성 (Lee et al., 1996; Kim et al., 1994a; Kim et al., 1994b; Lee et al., 2001), 식해의 기능성

\footnotetext{
*Corresponding author: kseaweed@kunsan.ac.kr
}

(Cha et al., 2002; Kim et al., 2001)에 관한 연구가 있지만 새로운 식해 개발에 관한 연구는 부족한 실정이다. 본 연구에 서는 위생상으로 안전하고 저장성도 우수한 패류식해를 개발 하기 위해 서해안에서 많이 생산되는 백합을 원료로 식해를 제조한 후 발효 과정 중 정미성분과 미생물 변화를 검토하였다.

$$
\text { 재료 및 방법 }
$$

재료

식해의 주원료인 백합은 2007년 5월에 전라북도 하제에서 각고 $45 \mathrm{~mm}$, 각장 $65 \mathrm{~mm}$ 정도인 것을 구입하여 사용하였고, 식해의 부원료인 메조, 엿기름, 식초, 조청, 올리고당, 고춧가 루, 마늘, 생강, 무 등은 2007년 5월 전라북도 군산 중앙시장에 서 구입하여 사용하였다.

\section{백합 식해제조}

백합 식해 제조 조건 설정을 위해 예비 실험을 통해 군산 대학교 교직원과 학생 37 명을 대상으로 색, 냄새, 맛, 조직감의 기호도를 조사하여 전처리 조건, 부원료 배합비, 발효 온도조 건을 선정하였다. 즉, 백합 껍질을 제거한 후 끓는 $2 \%$ 식염수 에 15 초간 담가 데친 후 체에 밭쳐 물기를 뺐다. 데친 백합 살을 조미액 (데친 백합 살을 기준으로 설탕 $10 \%, 2$ 배 식초 $10 \%$, 미림 $8 \%$, 간장 $2.5 \%$, 소금 $2.5 \%$ )에 넣고 냉장고에서 
12 시간 침지하였다. 조미된 백합에 메조 $(80 \%)$, 고춧가루 $(10 \%)$, 마늘 $(10 \%)$, 생강 $(1.6 \%)$, 엿기름분말 $(2.6 \%)$, 소금 (5.2\%)을 넣고 균일하게 혼합한 후 유리병에 넣어 밀봉한 후 45 일간 (상온에서 7 일간 발효시킨 후 $4{ }^{\circ} \mathrm{C}$ 에서 38 일간 숙성) 숙성시켰다.

염도, $\mathrm{pH}$, 산도, 아미노태 질소, 휘발성 염기 질소 ( VBN) 분석

염도는 Mohr법 (KFDA, 2008)으로 측정하였고, $\mathrm{pH}$ 는 $\mathrm{pH}$ meter (Orion model 420A, Orion, USA)로 측정하였다. 산도는 Cha et al. (2004a)에 따라 측정하였고, 아미노태 질소는 Formol 법 (KFDA, 2008)으로, VBN은 conway unit를 이용한 미량확산 법 (KFDA, 2008)으로 측정하였다. 각 분석값은 3 회 반복하여 평균값을 나타내었다.

정미 성분 분석

핵산관련물질은 Lee et al. (1984)의 방법에 따라 HPLC를 사용하여 분석하였고, 유기산은 핵산관련물질과 동일한 방법 으로 유기산을 추출한 후 Wang and Zhou (2006)의 방법에 따라 Aminex HPX-87H $(7.8 \times 300 \mathrm{~mm})$ column에 이동상으로 $4 \mathrm{mM}$ sulfuric acid를 분당 $0.5 \mathrm{~mL}$ 를 흘리면서 UV $210 \mathrm{~nm}$ 에서 측정하였다. 유리당은 시료에 3 배량의 $95 \%$ 에탄올을 첨가하 여 유리당을 추출한 후 Choi et al. (2002)에 따라 분석하였다. 유리아미노산은 Pico-tag method (Bilingmeyer, 1987)에 따라 분석하였다.

\section{미생물 측정}

총 균수의 측정은 plate count agar (Difco Co., Detroit, MI, $\mathrm{USA}$ )를 사용하여 $35^{\circ} \mathrm{C}$ 에서 48 시간 배양하여 집락수를 측정 하였다. 단백질분해 세균 측정은 plate count agar에 최종농도 $2 \%$ 의 skim milk를 넣은 배지를 사용하여 $35^{\circ} \mathrm{C}$ 에서 48 시간 배양한 후 colony 주위에 투명한 환을 생성하는 집락수를 측정 하였다. 효모측정은 potato dextrose agar (Difco Co., Detroit, $\mathrm{MI}, \mathrm{USA})$ 의 $\mathrm{pH}$ 를 $10 \%$ tartaric acid로 $\mathrm{pH} 3.5$ 로 조정한 후 $30{ }^{\circ} \mathrm{C}$ 에서 72 시간 배양하여 측정하였다. 젖산균의 측정은 bromophenol blue를 첨가한 Lactobacillus MRS agar (Difco Co., Detroit, MI, USA), m-Enterococcus agar (Difco Co., Detroit, MI, USA) 및 Elliker agar (Difco Co., Detroit, MI, USA)를 사용 하여 $30^{\circ} \mathrm{C}$ 에서 $48,72,96$ 시간 배양한 후 젖산균을 측정하였다. 비브리오균은 선택배지인 TCBS agar (Merck)를 사용하여 3 $5^{\circ} \mathrm{C}$ 에서 48 시간 배양한 후 측정하였다.

\section{결과 및 고찰}

발효 중 $\mathrm{pH}$ 및 총산의 변화

백합식해의 발효 중 $\mathrm{pH}$ 와 산도의 변화는 Fig. 1 과 같다. $\mathrm{pH}$ 는 담금 후 7일까지 $5.0 \sim 5.1$ 로 거의 변화가 없었으나 이 후 서서히 감소하여 45 일째에 $4.6 \sim 4.7$ 값을 나타내었다. 산도 도 7 일까지는 $0.4 \%$ 부근으로 거의 변화가 없었으나 이 후 서서히 증가하여 45 일째에 $0.7 \%$ 부근 값을 나타내었다.

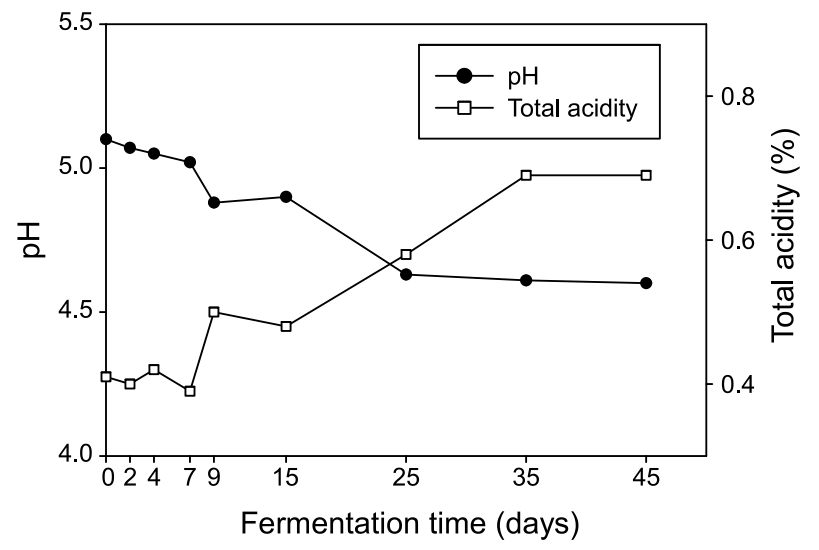

Fig. 1. Changes in $\mathrm{pH}$ and total acidity of hard clam sikhae during fermentation.

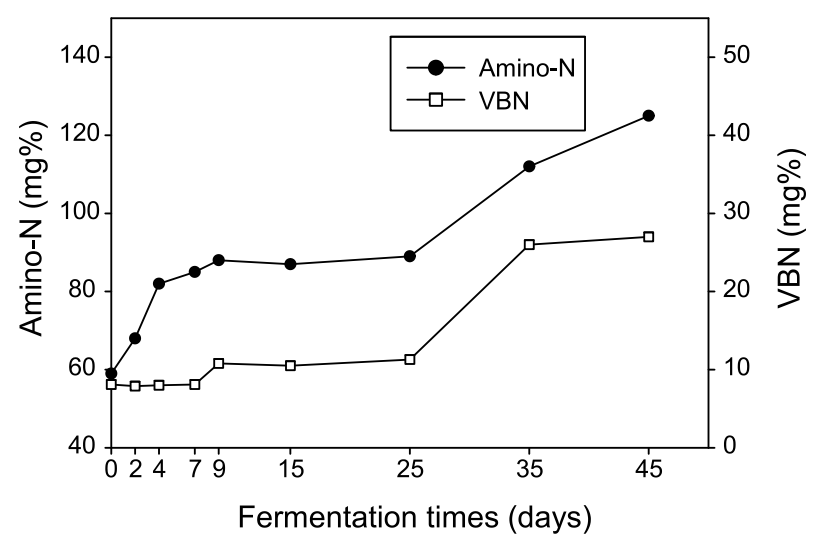

Fig. 2. Changes in amino-N and volatile basic nitrogen (VBN) concentrations of hard clam sikhae during fermentation.

반면에 전통적 방법으로 제조한 가자미식해(Lee et al., 1983), 오징어식해 (Lee et al., 2001), 명태식해 (Cha et al., 2004a)의 $\mathrm{pH}$ 는 담금 직후 $6.6 \sim 6.9$ 에서 숙성 $7 \sim 10$ 일째에 4.5 부근으로 급속히 감소하였다. 따라서 백합식해가 다른 식해에 비해 초 기 $\mathrm{pH}$ 가 낮고 발효 중 $\mathrm{pH}$ 의 저하 속도도 낮음을 알 수 있다. 이러한 차이는 blanching 및 식초가 함유된 조미액 침지과정에 서 초기 미생물 및 효소 활성이 감소되었기 때문으로 여겨진 다.

발효 중 아미노태 질소 및 휘발성 염기 질소 함량의 변화

백합식해의 발효 중 아미노태 질소와 휘발성 염기 질소 함량의 변화는 Fig. 2와 같다. 아미노태 질소는 담금 직후 약 $60 \mathrm{mg} / 100 \mathrm{~g}$ 에서 7일째 $85 \mathrm{mg} / 100 \mathrm{~g}$ 으로 급속히 증가한 후 이 후 완만히 증가하다가 25 일 후에 다시 급속히 증가하였다. 발효 45일째 백합식해의 아미노태 질소 함량 $130 \mathrm{mg} / 100 \mathrm{~g}$ 은 명 태식해의 아미노태 질소 $250 \mathrm{mg} / 100 \mathrm{~g}$ (Cha et al., 2004a), 오징어식해 $300 \mathrm{mg} / 100 \mathrm{~g}$ (Kim et al., 1994a), 가자미식해 $290 \mathrm{mg} / 100 \mathrm{~g}$ (Lee et al., 1983)에 비해 낮았으나 Choi et al. 
(2002)이 보고한 경상도 전통 마른 명태식해의 $113.3 \mathrm{mg} / 100$ $\mathrm{g}$ 에 비하여는 높았다. 이러한 차이는 원료의 종류, 배합비 및 원료 전처리 과정의 차이 때문으로 생각된다.

휘발성 염기 질소는 발효 7일까지 $8.0 \mathrm{mg} / 100 \mathrm{~g}$ 부근으로 거의 변화가 없었고 이후 서서히 증가하여 45 일째 $27.0 \mathrm{mg} / 100$ $\mathrm{g}$ 을 나타내었다. 반면에 가자미식해 (Lee et al., 1983)의 휘발 성 염기 질소는 담금 초기 약 $25 \mathrm{mg} / 100 \mathrm{~g}$ 에서 14 일째 150 $\mathrm{mg} / 100 \mathrm{~g}$ 으로, 명태식해 (Cha et al., 2004a)도 담금 초기 20 $\mathrm{mg} / 100 \mathrm{~g}$ 에서 20 일째 $50 \mathrm{mg} / 100 \mathrm{~g}$ 으로 증가하였다. 이러한 차이는 원료의 특성 및 제조 공정의 차이 때문으로 여겨진다. 특히 휘발성 염기 질소가 선도 및 비린내와 밀접한 관련이 있는 점을 미루어 볼 때 휘발성 염기 질소의 함량이 낮은 백합식해가 현대인의 기호에 적합할 것으로 생각된다.

\section{발효 중 유리당 및 유기산 함량의 변화}

발효 중 sucrose는 급격히 감소한 반면 fructose, maltose, glucose는 계속 증가하였다 (Table 1). Sucrose의 감소와 maltose, glucose, fructose의 증가는 설탕과 전분이 엿기름과 미생물에 의해 분해되었기 때문이다. 전통 명태식해 (Choi et al., 2002)의 유리당 함량은 glucose, maltose, lactose, maltotriose, fructose 순으로 높았는데 백합식해에서는 maltose, glucose, fructose 순으로 함량이 높았다. 이러한 차이 는 부원료의 조성 차이 때문으로 생각된다.

유기산 함량은 담금 직후에는 acetic acid와 succinic acid의 함량이 높았고, 45일 째는 lactic acid, acetic acid, succinic acid 의 함량이 높았다. 발효 초기 acetic acid와 succinic acid 함량이 높은 것은 조미액에 함유된 식초와 백합에 succinic acid가 전체 유기산의 $63.5 \%$ 로 가장 많이 함유되어 있기 때문이다 (Jo and Park, 1985). Lactic acid는 발효 7일까지는 검출이 되지 않았으나 9일부터 급속히 증가하여 45일째에 440.4 $\mathrm{mg} / 100 \mathrm{~g}$ 에 도달하였다. Lee et al. (2001)은 전통 마른오징어 식해의 발효 중 lactic acid의 증가가 현저하다고 하였고, Cha et al. (2004a)은 전통 명태 식해의 발효 중 lactic acid, citric acid 및 malic acid 순으로 식해의 신맛에 영향을 미친다고 하였다. 백합식해의 경우에는 lactic acid, acetic acid, succinic $\mathrm{acid}$ 가 가장 중요한 역할을 할 것으로 생각된다.

Table 1. Changes in free sugars concentrations of hard clam sikhae during fermentation

\begin{tabular}{ccccc}
\hline \multirow{2}{*}{ Fermentation days } & \multicolumn{5}{c}{ Free sugar $^{1)}$} \\
\cline { 2 - 5 } & Fructose & Glucose & Sucrose & Maltose \\
\hline 0 & 3.0 & 4.6 & 6.3 & 5.0 \\
2 & 4.6 & 6.4 & 2.5 & 6.4 \\
4 & 5.6 & 7.3 & 0.2 & 7.1 \\
7 & 6.3 & 8.3 & $-2)$ & 7.6 \\
9 & 6.1 & 7.9 & - & 8.4 \\
15 & 6.2 & 8.3 & - & 8.4 \\
25 & 6.5 & 9.3 & - & 10.1 \\
35 & 6.5 & 8.7 & - & 9.5 \\
45 & 6.5 & 9.6 & - & 10.1 \\
\hline
\end{tabular}

1) Concentration are on a dry weight and salt free basis $(\mathrm{g} / 100 \mathrm{~g})$.

2) - : Not detected.
Table 2. Changes in organic acids concentrations of hard clam sikhae during fermentation

\begin{tabular}{|c|c|c|c|c|c|c|c|c|c|}
\hline \multirow{2}{*}{$\begin{array}{l}\text { Organic } \\
\text { acid }^{11}\end{array}$} & \multicolumn{9}{|c|}{ Fermentation time (days) } \\
\hline & 0 & 2 & 4 & 7 & 9 & 15 & 25 & 35 & 45 \\
\hline Oxalic & 17.2 & 14.6 & 19.6 & 15.8 & 14.4 & 15.2 & 15.0 & 12.7 & 9.9 \\
\hline Citric & 138.6 & 118.6 & 126.2 & 131.4 & 104.3 & 125.0 & 78.8 & 70.7 & 48.5 \\
\hline Malic & 61.6 & -2) & 63.1 & 63.1 & 75.0 & 92.9 & 55.3 & 55.0 & 71.8 \\
\hline Succinic & 446.9 & 490.7 & 568.8 & 695.0 & 464.6 & 489.1 & 395.7 & 337.4 & 278.8 \\
\hline Lactic & - & - & - & - & 80.8 & 148.1 & 219.8 & 381.3 & 440.4 \\
\hline Acetic & 513.9 & 430.1 & 530.1 & 507.3 & 426.3 & 553.5 & 458.6 & 352.5 & 351.8 \\
\hline Total & $1,178.2$ & $1,054.0$ & $1,307.8$ & $1,412.6$ & $1,165.4$ & $1,423.8$ & $1,223.2$ & 1,209.6 1 & $1,201.2$ \\
\hline
\end{tabular}

발효 중 유리 아미노산과 핵산관련 물질 함량의 변화 총 유리아미노산 함량은 담금 직후 $716.2 \mathrm{mg} / 100 \mathrm{~g}$ 에서 45 일 째는 $1,404.9 \mathrm{mg} / 100 \mathrm{~g}$ 으로 증가하였다 (Table 3). 담금 직후에는 alanine, taurine, arginine의 3종이 총 유리아미노산의 $52.1 \%$ 를 차지하였으나 발효 45일째에는 alanine, taurine, glutamic acid, aspartic acid 4종이 전체 유리아미노산의 59.9\% 를 차지하였다. Glutamic acid와 aspartic acid는 감칠맛에 관여 하고, alanine은 단맛에 관여하는 점 (Hayashi et al, 1981 ; Cha et al., 2004a) 을 미루어 볼 때 alanine, glutamic acid, aspartic acid 3 종의 아미노산이 백합 식해의 맛에 직접적으로 관여할 것으로 판단된다.

Table 3. Changes in free amino acids concentrations of hard clam sikhae during fermentation

\begin{tabular}{lccccccccc}
\hline \multirow{2}{*}{ Amino acid") } & \multicolumn{10}{c}{ Fermentation time (days) } \\
\cline { 2 - 11 } & 0 & 2 & 4 & 7 & 9 & 15 & 25 & 35 & 45 \\
\hline Aspartic acid & 37.4 & 39.6 & 41.4 & 47.9 & 47.8 & 48.0 & 108.3 & 133.6 & 175.7 \\
Glutamic acid & 59.9 & 62.2 & 59.2 & 67.2 & 61.3 & 62.6 & 104.8 & 157.9 & 182.7 \\
Hydroxyproline & 40.5 & 39.3 & 38.5 & 22.8 & 36.3 & 35.5 & 71.1 & 60.6 & 94.3 \\
Serine & 9.8 & 19.8 & 10.0 & 13.8 & 12.7 & 17.7 & 37.7 & 41.0 & 70.8 \\
Glycine & 48.6 & 44.9 & 40.5 & 41.0 & 37.0 & 34.2 & 52.1 & 64.5 & 87.6 \\
Taurine & 114.9 & 110.9 & 100.9 & 114.6 & 107.7 & 98.2 & 129.1 & 172.1 & 222.4 \\
Histidine & 9.1 & $-2)$ & - & - & - & - & - & - & - \\
Threonine & 3.5 & - & - & - & - & - & - & - & - \\
Alanine & 151.1 & 151.0 & 149.4 & 139.8 & 129.9 & 126.1 & 156.3 & 198.9 & 260.3 \\
Arginine & 107.0 & 94.0 & 95.2 & 95.0 & 93.9 & 99.6 & 121.3 & 59.3 & 56.1 \\
Tyrosine & 7.4 & 10.7 & 11.1 & 9.4 & 9.1 & 11.1 & 17.1 & 17.9 & 14.4 \\
Valine & 8.9 & 10.1 & 11.6 & 13.6 & 13.7 & 14.0 & 17.4 & 39.5 & 32.8 \\
Methionine & 6.2 & - & - & - & - & - & - & - & - \\
Cystine & 68.7 & 94.2 & 85.2 & 53.6 & 69.9 & 61.3 & 94.2 & 92.4 & 100.8 \\
Leucine & 26.0 & 7.0 & 7.8 & 24.1 & 26.3 & 25.7 & 44.6 & 44.7 & 49.2 \\
Phenylanlanine & 13.1 & 16.4 & 15.4 & 20.5 & 19.8 & 20.2 & 34.4 & 44.0 & 57.8 \\
Lysine & 4.1 & - & - & - & - & - & - & - & - \\
\hline Total & 716.2 & 700.1 & 666.2 & 663.3 & 665.4 & 654.2 & 988.4 & 1126.4 & 1404.9 \\
\hline 1) Concentration & are & on a & dry & weight & and salt & free & basis \\
(mg/100g). & & & & & & &
\end{tabular}


Table 4. Changes in ATP related compounds concentrations of hard clam sikhae during fermentation

\begin{tabular}{lccccccccc} 
& \multicolumn{1}{c}{ Fermentation time (days) } \\
\cline { 2 - 11 } $\begin{array}{l}\text { ATP } \\
\text { related } \\
\text { compounds }\end{array}$ & 0 & 2 & 4 & 7 & 9 & 15 & 25 & 35 & 45 \\
\hline Hxpoxanthine & 0.6 & 0.7 & 1.0 & 1.3 & 1.3 & 1.5 & 1.8 & 1.5 & 1.3 \\
Inosine & 1.0 & 1.4 & 1.1 & 1.3 & 0.7 & 0.7 & 0.6 & 0.9 & 1.0 \\
\hline
\end{tabular}

Table 5. Changes in the number of microflora of hard clam sikhae during the fermentation

\begin{tabular}{|c|c|c|c|c|c|c|c|c|c|}
\hline \multirow{2}{*}{ Microflora } & \multicolumn{9}{|c|}{ Fermentation time (days) } \\
\hline & 0 & 2 & 4 & 7 & 9 & 15 & 25 & 35 & 45 \\
\hline $\begin{array}{l}\text { Total viable } \\
\text { jacteria }\end{array}$ & $2.1 \times 10^{5}$ & $2.5 \times 10^{5}$ & $6.3 \times 10^{5}$ & $4.4 \times 10^{7}$ & $4.3 \times 10^{8}$ & $4.4 \times 10^{8}$ & $4.0 \times 10^{8}$ & $3.8 \times 10^{8}$ & $3.5 \times 10^{8}$ \\
\hline $\begin{array}{l}\text { Proteolytic } \\
\text { bacteria }\end{array}$ & $1.2 \times 10^{5}$ & $1.6 \times 10^{5}$ & $2.8 \times 10^{5}$ & $9.4 \times 10^{6}$ & $6.0 \times 10^{7}$ & $9.8 \times 10^{7}$ & $7.5 \times 10^{7}$ & $1.3 \times 10^{7}$ & $9.0 \times 10^{6}$ \\
\hline Yeast & $2.4 \times 10^{3}$ & $2.8 \times 10^{3}$ & $8.5 \times 10^{3}$ & $4.5 \times 10^{5}$ & $6.0 \times 10^{6}$ & $5.9 \times 10^{6}$ & $1.6 \times 10^{7}$ & $8.8 \times 10^{6}$ & $2.2 \times 10^{6}$ \\
\hline $\begin{array}{l}\text { Lactic acid } \\
\text { bacteria }\end{array}$ & $3.6 \times 10^{4}$ & 3 & $4.2 \times 10^{4}$ & $8.0 \times 10^{7}$ & $5.0 \times 10^{8}$ & $4.9 \times 10^{8}$ & $4.8 \times 10^{8}$ & $4.8 \times 10^{8}$ & $4.7 \times 10^{8}$ \\
\hline
\end{tabular}

핵산관련 물질은 담금 직후에도 $\mathrm{ATP}, \mathrm{ADP}, \mathrm{AMP}, \mathrm{IMP}$ 는 검출되지 않았다 (Table 4). 발효 중에 hypoxanthin과 inosine의 함량도 일부 미량 검출되었으나 백합 식해의 맛에 기여 정도 는 미미 할 것으로 판단된다.

발효 중 총 균수 및 단백질 분해 세균의 변화

발효 중 총 균수의 변화는 담금 직후 $2.1 \times 10^{5} \mathrm{CFU} / \mathrm{g}$ 에서 15 일째 $4.4 \times 10^{8} \mathrm{CFU} / \mathrm{g}$ 까지 증가한 후 서서히 감소하여 발효 45 일째에는 $3.5 \times 10^{8} \mathrm{CFU} / \mathrm{g}$ 이였다 (Table 5). 오징어식해 (Kim et al., 1994b)와 명태식해 (Cha et al., 2004b)의 경우 숙성 10 일 경에 각각 $3.4 \times 10^{9} \mathrm{CFU} / \mathrm{g}, 2.6 \times 10^{9} \mathrm{CFU} / \mathrm{g}$ 로 최고치에 도달한 후 서서히 감소하였다. 총 균수의 최고치에 있어 백합식해가 오징어식해보다 약 7.7 배, 명태식해보다 약 6배 정도 낮았다. 이러한 차이는 blanching, 식초를 함유한 조미액에 침지, 발효 온도의 차이 때문으로 생각된다.

단백질분해 세균은 담금 직후 $1.2 \times 10^{5} \mathrm{CFU} / \mathrm{g}$ 에서 저장 15 일째에 최고치인 $9.8 \times 10^{7} \mathrm{CFU} / \mathrm{g}$ 에 도달한 후 서서히 감소 하여 저장 45 일에는 $9.0 \times 10^{6} \mathrm{CFU} / \mathrm{g}$ 이였다 (Table 5). 단백질분 해 세균의 변화 경향은 총 균수와 유사하였으며 최고치를 나타낸 발효 15 일째의 단백질분해 세균은 총 균수의 약 $22 \%$ 를 차지하였다. Lee et al. (1983)은 가자미식해에서 단백질분해 세균은 숙성 14 일경에 $10^{4} \sim 10^{5} \mathrm{CFU} / \mathrm{g}$ 으로 최고치에 도달한 후 급격히 감소하였다고 보고하였으며, Cha et al. (2004b)은 명태식해를 $5^{\circ} \mathrm{C}$ 및 $20^{\circ} \mathrm{C}$ 에서 숙성하였을 경우, 숙성 12 일경에 단백질분해 세균은 각각 $8.2 \times 10^{6}$ 및 $6.5 \times 10^{8} \mathrm{CFU} / \mathrm{g}$ 의 최고치 에 도달한 후 서서히 감소한다고 보고하였다.

발효 중 효모의 변화

발효 중 효모의 변화는 Table 5와 같다. 담금 직후 $2.4 \times$
$10^{3} \mathrm{CFU} / \mathrm{g}$ 에서 발효 기간의 경과에 따라 증가하여 저장 25 일 째에 최고치인 $1.6 \times 10^{7} \mathrm{CFU} / \mathrm{g}$ 에 도달한 후 서서히 감소하였 다. Cha et al. (2004b)은 명태식해의 숙성 중 효모의 변화는 $5^{\circ} \mathrm{C}$ 에서는 $10^{4} \mathrm{CFU} / \mathrm{g}$ 전후로 적고, $20^{\circ} \mathrm{C}$ 에서는 저장 18 일까지 약간의 증감이 있다가 23 일경에는 다시 급격히 증가한다고 보고하였다. 백합식해의 경우, 명태식해보다는 효모수가 많은 편이며, 효모가 최고치에 도달하는데 걸리는 시간은 세균보다 10 여일 늦게 나타나는 특징이 있었다. 이는 일반적으로 세균 보다는 효모의 생육최적 온도가 낮다는 점과 효모에도 각각 생육최적 온도 범위가 다르기 때문으로 생각된다.

발효 중 젓산균의 변화

발효 중 젖산균의 변화는 Lactobacillus MRS agar, m-Enterococcus agar 및 Elliker agar에 나타난 결과가 거의 유사하였기 때문에 Lactobacillus MRS agar에서 나타난 결과 로 나타내었다. 초기의 젖산균수는 $3.6 \times 10^{4} \mathrm{CFU} / \mathrm{g}$ 이였으나, 저장 기간에 따라 증가하여 저장 9 일째 최고치인 $5.0 \times 10^{8}$ $\mathrm{CFU} / \mathrm{g}$ 에 도달한 후 45일 까지 거의 변화가 없었다 (Table 5). Jo et al. (1997)은 저염 조미 오징어 젓갈을 $10^{\circ} \mathrm{C}$ 에서 숙성시 키면서 경시적인 젖산균수의 변화를 조사한 결과 젖산균은 숙성적기에서 급격히 증가하고 이때 총 균수의 대부분은 젖산 균이 차지한다고 보고하였다. Cha et al. (2004b)은 명태식해를 $20^{\circ} \mathrm{C}$ 에서 숙성하면 젖산균인 Latobacillus 속은 10 일경에 최고 치 $1.2 \times 10^{9} \mathrm{CFU} / \mathrm{g}$ 에 이른 다음 저장 30 일까지 거의 변화가 없으며, Leuconostoc속은 숙성 3 일경에 최고치 $7.0 \times 10^{6} \mathrm{CFU} / \mathrm{g}$ 에 이른 후 급격히 감소하며, Pediococcus속은 5일경에 최고치 $10^{8} \mathrm{CFU} / \mathrm{g}$ 에 이른 다음 서서히 감소하며, Streptococcus 속은 9일째에 최고치 $1.7 \times 10^{7} \mathrm{CFU} / \mathrm{g}$ 에 이른다고 보고하고 있다. 보고된 명태식해와 백합식해의 결과를 비교해보면, 명태식해 보다는 젖산균수가 적게 나타났으나 숙성과정중의 젖산균의 변화양상은 유사하였다. 또한 저장 7일째 이후에는 총 균수보 다 총 젖산균수가 많아져 저장 7일째 이후에 백합식해에 존재 하는 세균은 대부분 젖산균일 가능성이 높다고 생각된다.

식해 발효 중 비브리오속의 변화

비브리오속은 주재료인 백합을 전 처리 과정에서 데쳤기 때문에 존재 가능성은 낮으나 제조직후부터 발효 7일째까지 4회에 걸쳐 존재를 확인한 결과 비브리오속의 선택배지인 $\mathrm{TCBS}$ 배지에서 colony가 전혀 확인되지 않았다(data not shown)

$$
\text { 사 사 }
$$

이 논문은 2007년 호남 seagrant 학술 용역비 지원에 의하여 연구되었습니다.

\section{참고문헌}

Bidlingmeyer, BA, Cohen SA and Tarvin TL. 1987. A new rapid, high sensitivity analysis of amino acid in food type samples. Journal of Official Analysis Chemistry 70, 241-247. 
Cha YJ, Lee CE, Jeong EK, Kim H and Lee, JS. 2002. Physiological functionalities of traditional Alaska pollack sikhae. J Korean Soc Food Sci Nutr 31, 559-565.

Cha YJ, Kim SJ, Jeong EJ, Kim H, Cho WJ and Yoo MY. 2004a. Studies on taste compounds in Alaska pollack sikhae during fermentation. J Korean Soc Food Sci Nutr 33, 1515-1521.

Cha, Y.J., S.J. Kim, E.J. Jeong, H. Kim and W.J. Cho. 2004b. Microbiological and enzymatic characteristics in Alaska pollack sikhae during fermentation. J Korean Soc Food Sci Nutr 33, 1709-1714.

Choi C, Koo TH, Kim S, Choi HJ and Seung TS. 2002. A study on quality characteristics of traditional Kyungsangdo Myungtae (Alaska pollack) sikhae. Korean J Dietary Culture 17, 267-274.

Hayashi T, Yamaguchi K and Konos S. 1978. Studies on flavor compounds in boiled crabs- $\Pi$ : Nucleotides and organic bases in the extracts. Bull Japan Soc Fish 44, 1357-1362.

Jo JH, Oh SW, Kim YM, Chung DH and KIm JI. 1997. Changes in lactic acid bacteria of squid with low salt during fermentation. Korean J Food Sci Technol 29, 5-9.

Jo KS and Park YH. 1985. Studies on the organic acids composition in shellfishes 1. Nonvolatile organic acids composition of top shell, hard clam, abalone and their boiled-dried products. Bull Korean Fish Soc 18, 227-234.

Jung HS, Lee SH and Woo KL. 1992. Effect of salting levels on the changes of taste constituents of domestic fermentation flounder sikhae of Hamkyengdo. Korean J Food Sci Technol 24, 59-64.

Kim KP, Rhee CH and Park HD. 2001. Isolation and characterization of cholesterol degradation bacteria from korea traditional salt fermented flat fish. Korean J Postharvest Sci Technol 8, 92-101.
Kim SM, Jeong IH and Cho YJ. 1994a. The development of squid (Todarodes pacificus) sik-hae in Kangnung district. Bull Korean Fish Soc 27, 215-222.

Kim SM, Cho YJ and Lee KT. 1994b. The development of squid (Todarodes pacificus) sik-hae in Kang-nung district. Bull Korean Fish Soc 27, 223-231.

Korea food and drug administration. 2004. Food Code. Korean Food and Drug Administration, Seoul, Korea, 1-164.

Lee $\mathrm{CH}$, Cho TS, Lim MH, Kang JW and Yang HC. 1983. Studies on the sik-hae fermentation made by flat-fish. Kor J Appl Microbiol Bioeng 11, 53-58.

Lee HD, Choi HJ, Kim S, Seung TS and Choi C. 2001. Identification of lactic acid bacteria and changes of organic acid during aging of traditional Kyungsando squid sikhae. J Korean Soc Agri Chem Biotechnol 44, 167-172.

Lee MY and Lee HG. 1989. A bibliographical study on the shikke. Korean J dietary culture 4, 39-51.

Lee NH, Oh SW and Kim YM. 1996. Biochemical changes in muscle protein of squid sikhae during fermentaion-Effects of temperature and moisture content. Korean J Food Sci Technol 28, 291-297.

Wang P and Zhou R. 2006. Determination of organic acids exuded from plant roots by high performance liquid chromatography. Chin J Chrom 24, 239243.

Souane M, Kim YB and Lee CH. 1987. Microbial chracterization of gajami sik-hae fermentation. Kor J Appl Microbiol Bioeng 15, 150-157.

2009년 10월 15 일 접수

2009년 11월 27일 수정

2009년 12월 18일 수리 